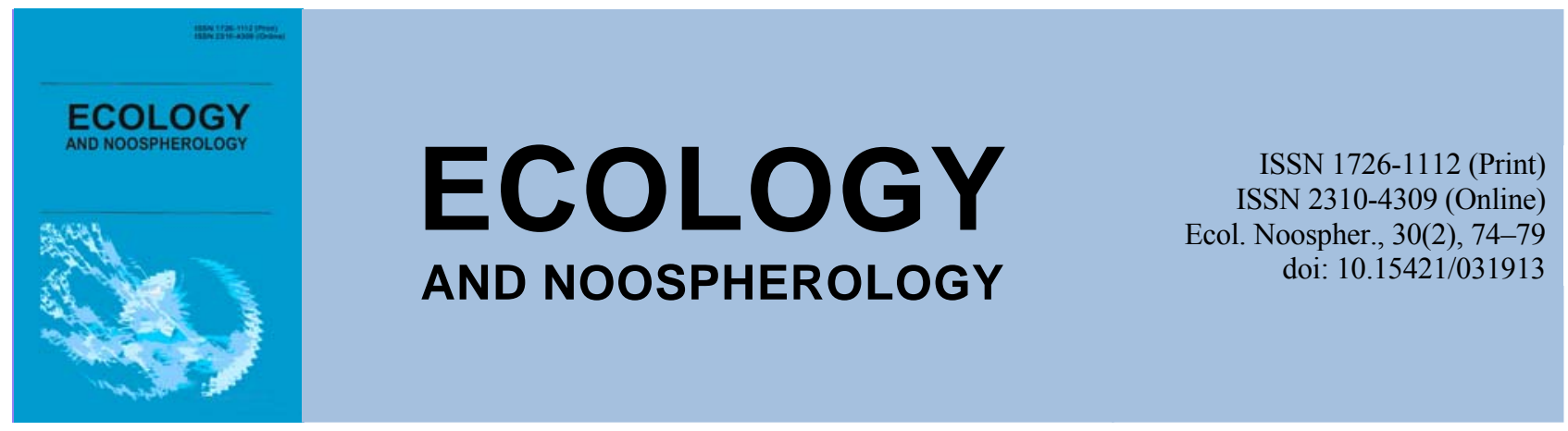

\title{
Features of the structural-aggregate composition of ordinary chernozems under the steppe and forest vegetation
}

\author{
V. A. Gorban, A. O. Boloban \\ Oles Honchar Dnipro National University, Dnipro, Ukraine
}

Article info

Received 08.10.2019

Received in revised form

15.10.2019

Accepted 27.10.2019

Oles Honchar Dnipro

National University,

Gagarin Ave., 72, Dnipro,

49010, Ukraine.

Tel.: +38-050-362-45-90

E-mail:vad01@ua.fm
Gorban, V. A., Boloban, A. O. (2019). Features of the structural-aggregate composition of ordinary chernozems under the steppe and forest vegetation. Ecology and Noospherology, 30(2), 74-79. doi:10.15421/031906

The structural-aggregate composition is an important soil characteristic, which reflects the features of the genesis, condition and regimes of soils. The structural and aggregate composition of ordinary chernozems under zonal steppe vegetation and under artificial forest plantations from white acacia and common oak in the conditions of the Prisamaría was studied. As a result, it was found that in all the studied soils the greatest content falls on the fraction $2-1 \mathrm{~mm}$ in size. In ordinary chernozems in the upper horizons, under the stands of white acacia and common oak, an increase in the content of this agronomically valuable fraction is observed. Also in ordinary chernozem under forest stands, an increase in the value of the structural coefficient is observed compared with ordinary chernozem under steppe vegetation. In ordinary chernozem the most favorable effect of the growth of white acacia was found in horizon $\mathrm{H}$, and the growth of ordinary oak in horizon $\mathrm{H} 2$, in which the highest values of the structural coefficient were found. In the studied ordinary chernozems under the steppe and forest vegetation a predominance of the water-resistant fraction of size $<0.25 \mathrm{~mm}$ is observed. The positive effect of white acacia and common oak plantations on the water resistance of aggregates of common chernozem in the upper horizons is manifested in a decrease in the content of the fraction of size $<0.25 \mathrm{~mm}$ compared to ordinary chernozem. In ordinary chernozems under steppe vegetation the most favorable conditions for the formation of agronomically valuable fractions during dry sieving are characteristic of the lower horizons and for chernozems under forest stands in the upper horizons. In all the studied soils the highest content of agronomically valuable fractions during wet sieving was found in the upper horizons, but there are more of them in chernozems under forest stands. The highest content of agronomically valuable fractions in all studied soils is observed in the lower horizons and their highest content in the upper horizons is found in ordinary chernozems under the steppe vegetation. The highest values of the water resistance criterion are characteristic of the lower horizons of the studied chernozems. The maximum values of this criterion were found in ordinary chernozem under oak plantation, and the smallest - under acacia plantation. The growth of forest plantations on ordinary chernozems leads to an improvement in their structural-aggregate composition.

Keywords: ordinary chernozems; agronomically valuable fraction; water resistance; acacia plantation; oak plantation

\section{Особливості структурно-агрегатного складу чорноземів звичайних під степовою та лісовою рослинністю}

\author{
В. А. Горбань, А. О. Болобан
}

Дніпровський національний університет імені Олеся Гончара, Дніпро, Украӥна

Структурно-агрегатний склад є важливою грунтовою характеристикою, яка відображає особливості генезису, стану та режимів грунтів. Досліджувався структурно-агрегатний склад чорноземів звичайних під зональною степовою рослинністю, а також під штучними лісовими насадженнями 3 акації білої та дуба звичайного в умовах Присамар'я. В результаті встановлено, що в усіх досліджених грунтах найбільший уміст припадає на фракцію розміром 2-1 мм. У чорноземі звичайному під лісовими насадженнями спостерігається збільшення величини коефіцієнта структурності порівняно 3 
чорноземом звичайним під степовою рослинністю. У досліджених чорноземах звичайних під степовою та лісовою рослинністю спостерігається переважання водостійкої фракції розміром $<0,25$ мм. У чорноземах звичайних під степовою рослинністю найбільш сприятливі умови для формування агрономічно цінних фракцій при сухому просіюванні характерні для нижніх горизонтів, а для чорноземів під лісовими насадженнями - у верхніх горизонтах. В усіх досліджуваних грунтах найбільший уміст агрономічно цінних фракцій при мокрому просіюванні виявлено у верхніх горизонтах, однак в чорноземах під лісовими насадженнями він більший. Найбільший уміст агрономічно цінних фракцій в усіх досліджуваних грунтах спостерігається в нижніх горизонтах, а їх найбільший уміст у верхніх горизонтах виявлено в чорноземах звичайних під степовою рослинністю. Найбільші значення критерію водоміцності характерні для нижніх горизонтів досліджуваних чорноземів. Максимальні значення зазначеного критерію виявлені в чорноземі звичайному під насадженням дуба, а найменші - під насадженням акації. Зростання лісових насаджень на чорноземах звичайних сприяє покращенню їх структурно-агрегатного складу.

Ключові слова: чорноземи звичайні; агрономічно цінна фракція; водостійкість; насадження акації; насадження дуба

\section{Вступ}

Структурно-агрегатний склад - це певний внутрішньогоризонтний рівень організації грунтового тіла, що відображає особливості грунтоутворення певної місцевості, який можна охарактеризувати розміром, формою, щільністю укладання структурних одиниць, зовнішніми та внутрішніми властивостями, а також специфічною динамікою, що також відображає коливання факторів агрегації та деагрегації (Voronin, 1986; Medvedev, 2008). Як відомо, структурність грунту, а також якісні характеристики його агрегатів (розміри, водостійкість, механічна міцність) істотно залежать від гранулометричного складу (Horn et al., 1994; Medvedev, Laktionova, 2011), достатньої наявності та особливостей органічної речовини (Monreal et al., 1995; Shein, Milanovskii, 2003; Degtyarev, 2011), складу поглинутих катіонів (Belova, Travleyev, 1999; Desyatnik, 2015), розвитку кореневих систем рослин та активної діяльності грунтової мезофауни і мікроорганізмів (Medvedev, 2008; Shein, Milanovskiy, 2014). Форма структурних агрегатів може служити діагностичною ознакою, яка відображає генетичні особливості певного типу грунту (Karpachevsky, 2005) та його природну родючість (Šimanský, 2015). Розподіл розмірів агрегатів грунту і стабільність структури $\epsilon$ важливими показниками фізичної якості грунту (Gholoubi et al., 2019).

На сьогодні основні дослідження присвячені встановленню особливостей структурного складу чорноземів, які використовуються в сільському господарстві (Cherednichenko, 2015; Pituello et al., 2016; Krylach, 2016; Gorban, 2018), в той же час недостатньо дослідженими залишаються особливості формування структурно-агрегатного складу чорноземів під лісовою рослинністю. Виходячи 3 цього, метою нашої роботи $\epsilon$ встановлення особливостей структурно-агрегатного складу чорноземів звичайних, які сформувалися під штучними лісовими насадженнями.

\section{Об’скти та методи досліджень}

Дослідження впливу лісової рослинності на діелектричну проникність та електрофізичні показники чорноземів виконували на грунтових зразках, відібраних 3 чорноземів звичайних (пробна площа № 201 - еталон, степова цілина), чорноземів під насадженням акації білої (пробна площа № 224-а) та під насадженням дуба звичайного (пробна площа № 224-д).

Пробна площа № 201. Розташована на вододілі річок Самари та Сороковушки. Це мікроплато зі схилом 4-5 північно-східної експозиції. Режим зволоження відповідає сухим місцезростанням $\mathrm{C}_{0-1}$.

У живому покриві ковила Лессінга (Stipa Lessingiana); інколи на більш крутих ділянках схилів - ковила волосиста (S. capillata); костриця валіська (Festuca valesiaca); чебрець Маршаллів (Thymus marschalliana); сальвія зникла та дібровна (Salvia nutans, S. nemorosa); самосил білоповстистий (Teucrium polium); люцерна румунська
(Medicago romanica); деревій звичайний (Achillea millefolium); молочаї (Euphorbia sp.); парило звичайне (Agrymonia eupatoria).

Макроморфологічний опис трунтового розрізу ПП № 201

$\mathrm{H}_{0}(0-1$ см) - одношаровий фрагментарний калдан.

$\mathrm{H}_{1}(0-7$ см) - темно-сірий сухуватий суглинок зернистої структури з пилуватістю. Пухкий, корененасичений, з рідкими вкрапленнями присипки. Велика кількість пор. Горизонт насичений копролітами. Перехід поступовий за кольором.

$\mathrm{H}_{2}$ (7-26 см) - темно-сірий з буруватістю, яка зростає донизу; сируватий, структура зерниста, пухкий, 3 присипкою, багато копролітних утворень; проникність коренями помітно менша, перехід більш-менш різкий за кольором та структурністю.

Нp (26-56 см) - сіро-бурий та буруватий із затіками та плямами сірого та темно-сірого кольору; свіжуватий суглинок; пласти розпадаються на зернисті та грудкуваті окремості; більш щільний, але ще пухкий; невелика тріщинуватість; проникнений великими коренями; місцями псевдоміцелій; перехід помітний за кольором, структурою, щільністю. Закипання з $48 \mathrm{~cm}$.

Phk (56-85 cм) - палево-жовтий з сіро-бурими та бурими варіаціями; свіжуватий; вертикальні стовпчасті пласти розпадаються на грудкуваті окремості та піскоподібну масу; суглинок; розвинена тріщинуватість; окремі затіки гумусової речовини, окремі великі корені, кротовина; по нижній межі починається білозірка; перехід різкий.

Рк $(85-150$ см $)$ - палево-жовтий, жовто-бурий, свіжуватий, пухкий стовпчастий макроструктурний лесовий суглинок (материнська порода); рясна білозірка; тріщинуватість; окремі затіки сірої речовини по кореневих ходах; корені рідко зустрічаються; кротовина; перехід різкий за структурою, щільністю та кольором.

Ірунт - чорнозем звичайний карбонатний малогумусовий слабкозмитий середньосуглинковий на лесових відкладах (Belova, Travleyev, 1999).

Пробна площа № 224-a. Знаходиться на вододільному плато західніше с. Всесвятського Новомосковського р-ну Дніпропетровської обл. Тип лісорослинних умов $-\mathrm{C}_{1}$ (суглинок сухуватий). Грунтові води 3 глибини 40 м. Тип світлової структури - напівосвітлений. Світловий стан нормальний. Тип деревостану - 10 Ак. б., вік насадження 60 років, висота - 7-9 м, діаметр стовбурів - 8-12 см. Зімкнутість деревостану $-0,7$.

Макроморфологічний опис трунтового розрізу ПП № 224-а

$\mathrm{H}_{01}(0-1 \mathrm{~cm})$ - лісова підстилка складається 3 листя акації.

$\mathrm{H}_{02}$ (1-3 см) - підстилка 3 напіврозкладеного листя акації.

Н (0-14 см) - темно-сірий, сухуватий, грудкуватий, суглинковий, пухкий. Містить багато коренів трав'янистої рослинності. Перехід за щільністю та кольором.

Нp (14-34 см) - перехідний горизонт. Сірий з бурим відтінком, сухуватий, грудкуватий, суглинковий, щільний. Зустрічаються поодинокі корені. Перехід за кольором та щільністю.

Phk (34-56 см) - темно-бурий, сухуватий, грудкуватий, суглинковий, дуже щільний. Зустрічаються поодинокі корені. Перехід за кольором та включенням білозірки. Закипання $353 \mathrm{~cm}$. 
Pk (56-120 см) - материнська порода - лесоподібний суглинок. Бурий, сухуватий, суглинковий, дуже щільний, 3 включенням білозірки.

Грунт - чорнозем звичайний лісопокращений слабковилужений малогумусовий середньосуглинковий на лесах.

Пробна площча № 224-d. Знаходиться на вододільному плато західніше пробної площі № 224-а. Тип лісорослинних умов - СГ 1 (суглинок сухуватий). Грунтові води 3 глибини 40 м. Тип світлової структури - тіньовий. Світловий стан нормальний. Чагарниковий підлісок - 3 клену татарського, зімкнутість 0,5. Тип деревостану - 10 Д. зв., вік насадження - 70 років, висота - 8-10 м, діаметр стовбурів - 10-14 см. Зімкнутість деревостану - 0,8.

Макроморфологічний опис грунтового розрізу ПП № 224-д

$\mathrm{H}_{01}(0-3 \mathrm{~cm})$ - лісова підстилка складається 3 листя дуба.

$\mathrm{H}_{02}$ (3-5 см) - напіврозкладена, трухоподібна маса, міцно поєднана $з$ грунтом.

$\mathrm{H}_{1}$ (0-10 см) - темно-сірий, сухуватий, грудкуватий, суглинковий, пухкий. Включає багаточисельні корені трав'янистої рослинності. Перехід за щільністю, кольором та насиченістю коренями.

$\mathrm{H}_{2}$ (10-35 см) - темно-сірий, сухуватий, грудкуватий, суглинковий, щільніший за попередній. Корененасиченість зменшується, зустрічаються поодинокі корені дуба. Перехід за кольором та щільністю.

Hр (35-70 см) - перехідний горизонт. Сірий 3 вкрапленням бурого кольору, сухуватий, дрібногрудкуватий, суглинковий, щільний. Перехід за кольором. Закипання з $43 \mathrm{~cm}$.

Phk (70-100 см) - сірувато-бурий, сухуватий, грудкуватої структури, суглинковий, щільний. Перехід за кольором та щільністю.

Pk (100-150 см) - материнська порода - лесоподібний суглинок. Бурий, сухуватий, суглинковий, дуже щільний.

Грунт - чорнозем звичайний лісопокращений карбонатний малогумусовий середньосуглинковий на лесах (Belova, 1997).

Визначення структурно-агрегатного складу досліджених грунтів виконували ситовим методом у модифікації Н. I. Саввінова (DSTU 4744:2007).

\section{Результати та їх обговорення}

При встановленні особливостей агрегатного складу чорноземів звичайних під степовою рослинністю виявлено, що у верхніх горизонтах $\mathrm{H}_{1}$ та $\mathrm{H}_{2}$ найбільший уміст фракцій припадає на розмір $2-1$ мм $(20,0$ та $26,2 \%$ відповідно). У нижніх горизонтах спостерігається переважання фракцій більшого розміру (табл. 1). Також у верхніх горизонтах спостерігається найбільший уміст фракції розміром $<0,25$ мм. У цілому для генетичних горизонтів досліджуваного грунтового розрізу характерна відсутність агрегатів фракції розміром $>10$ мм. Величина коефіцієнта структурності, який розраховується як співвідношення суми агрономічно цінних агрегатів розміром від 0,25 до 10 мм до суми агрегатів розміром $<0,25$ та $>10$ мм (Vadyunina, Korchagina, 1986), досягає максимального значення 42,7 у горизонті Phk. При цьому його мінімальну величину $(8,5)$ виявлено у верхньому горизонті $\mathrm{H}_{1}$, а $з$ глибиною спостерігається зростання його величини.

Аналіз розподілу фракцій в чорноземі звичайному під насадженнями акації білої показав, що максимальний уміст фракцій розміром 2-1 мм, як і в чорноземі звичайному під степовою рослинністю, спостерігається у верхніх горизонтах Н та Нр (25,6 та 19,1 \% відповідно). У нижніх горизонтах Phk та Pk відбувається зростання вмісту фракцій більшого розміру, які в цих горизонтах переважають. Для верхніх горизонтів Н та Нр характерна відсутність фракції розміром $>10$ мм, а в горизонті $\mathrm{Pk}$ ця фракція та фракція 10-7 мм вже $\epsilon$ переважаючими. Максимальне значення коефіцієнта структурності виявлено в горизонті Н $(22,8)$, $з$ глибиною спостерігається його поступове зниження.

$\mathrm{y}$ чорноземах звичайних під насадженням дуба звичайного у верхніх горизонтах $\mathrm{H}_{1}$ та $\mathrm{H}_{2}$ переважають фракції розміром $2-1$ та $1-0,5$ мм. Також у цих горизонтах відсутня фракція розміром $>10$ мм. У нижніх горизонтах спостерігається домінування фракцій більшого розміру. Максимальне значення коефіцієнта структурності виявлено в горизонті $\mathrm{H}_{2}(24,2)$, 3 глибиною спостерігається поступове зменшення його величини.

Таблиця 1

Агрегатний склад чорноземів звичайних під степовою та лісовою рослинністю

\begin{tabular}{|c|c|c|c|c|c|c|c|c|c|c|c|}
\hline \multirow[b]{2}{*}{$\begin{array}{c}\text { Гене- } \\
\text { тичний } \\
\text { горизонт }\end{array}$} & \multirow[b]{2}{*}{$\begin{array}{c}\text { Глибина, } \\
\text { см }\end{array}$} & \multicolumn{9}{|c|}{ Уміст фракцій (мм), \% } & \multirow[b]{2}{*}{$\begin{array}{l}\text { Коефі- } \\
\text { цієнт } \\
\text { структур- } \\
\text { ності }\end{array}$} \\
\hline & & $\stackrel{\circ}{\wedge}$ & $\underline{\jmath}$ & $\stackrel{i}{r}$ & in & in & ন & $\stackrel{n}{1}$ & 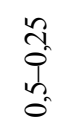 & $\begin{array}{l}\tilde{n} \\
\hat{\theta} \\
\hat{v}\end{array}$ & \\
\hline \multicolumn{12}{|c|}{ Пробна площа № 201 - чорнозем звичайний під степовою рослинністю } \\
\hline $\mathrm{H}_{1}$ & $0-7$ & 0,0 & 7,4 & 11,4 & 9,1 & 12,7 & 20,0 & 15,1 & 13,7 & 10,5 & 8,5 \\
\hline $\mathrm{H}_{2}$ & $7-26$ & 0,0 & 6,2 & 10,0 & 13,7 & 20,9 & 26,2 & 9,9 & 6,1 & 6,9 & 13,6 \\
\hline $\mathrm{Hp}$ & $26-56$ & 0,0 & 16,6 & 13,3 & 13,2 & 19,1 & 18,6 & 7,5 & 6,0 & 5,8 & 16,3 \\
\hline Phk & $56-85$ & 0,0 & 19,2 & 21,8 & 14,0 & 18,6 & 14,7 & 6,2 & 3,2 & 2,3 & 42,7 \\
\hline $\mathrm{Pk}$ & $85-150$ & 0,0 & 9,3 & 16,4 & 12,2 & 20,1 & 24,0 & 9,5 & 4,6 & 4,1 & 23,7 \\
\hline
\end{tabular}

Пробна площа № 224-а - чорнозем звичайний під насадженням акації білої

\begin{tabular}{cccccccccccc}
$\mathrm{H}$ & $0-14$ & 0,0 & 11,2 & 10,1 & 10,7 & 18,0 & 25,6 & 14,0 & 6,2 & 4,2 & 22,8 \\
$\mathrm{Hp}$ & $14-34$ & 0,0 & 9,1 & 10,9 & 10,2 & 16,1 & 19,1 & 15,4 & 10,4 & 8,9 & 10,3 \\
$\mathrm{Phk}$ & $34-56$ & 4,3 & 18,4 & 13,6 & 12,6 & 14,1 & 13,5 & 10,2 & 6,7 & 6,7 & 8,1 \\
$\mathrm{Pk}$ & $56-120$ & 17,4 & 17,9 & 11,6 & 7,0 & 8,6 & 10,2 & 9,0 & 8,2 & 10,1 & 2,6 \\
\hline
\end{tabular}

\begin{tabular}{cccccccccccc}
\hline \multicolumn{8}{c}{ Пробна площа № 224-д - чорнозем звичайний під насадженням дуба звичайного } \\
$\mathrm{H}_{1}$ & $0-10$ & 0,0 & 5,0 & 6,7 & 9,7 & 16,4 & 24,0 & 21,0 & 9,4 & 7,8 & 11,9 \\
$\mathrm{H}_{2}$ & $10-35$ & 0,0 & 7,3 & 10,3 & 13,3 & 17,4 & 22,7 & 17,5 & 7,5 & 4,0 & 24,2 \\
$\mathrm{Hp}$ & $35-70$ & 2,4 & 16,7 & 17,0 & 13,2 & 17,8 & 16,2 & 8,6 & 4,5 & 3,7 & 15,5 \\
$\mathrm{Phk}$ & $70-100$ & 12,7 & 28,1 & 15,3 & 10,3 & 11,2 & 10,3 & 6,2 & 3,1 & 3,0 & 5,4 \\
$\mathrm{Pk}$ & $100-150$ & 8,3 & 18,6 & 16,9 & 10,7 & 11,9 & 12,5 & 9,3 & 5,9 & 5,9 & 6,1 \\
\hline
\end{tabular}


Таким чином, в усіх досліджених грунтах найбільший уміст припадає на фракцію розміром $2-1$ мм, а зростання на чорноземах звичайних насаджень акації білої та дуба звичайного сприяє збільшенню вмісту цієї агрономічно цінної фракції у верхніх горизонтах чорноземів звичайних. Також у чорноземі звичайному під лісовими насадженнями спостерігається збільшення величини коефіцієнта структурності порівняно 3 чорноземом звичайним під степовою рослинністю, що погоджується з висновками, отриманими Н. А. Біловою (Belova, 1997). У чорноземі звичайному найбільш сприятливий вплив зростання акації білої виявлено в горизонті $\mathrm{H}$, а зростання дуба звичайного у горизонті $\mathrm{H}_{2}$, в яких виявлено найбільші значення коефіцієнта структурності.
При дослідженні водостійкості структурних агрегатів генетичних горизонтів чорноземів звичайних під степовою рослинністю виявлено, що переважає фракція розміром $<0,25$ мм (табл. 2). При цьому спостерігається поступове зменшення вмісту цієї фракції з глибиною, а максимальний іiї вміст виявлено в горизонті $\mathrm{Pk}\left(50,6\right.$ \%). У горизонтах $\mathrm{H}_{1}, \mathrm{H}_{2}$ та Нр спостерігається також збільшений уміст водостійкої фракції розміром $1-0,5$ мм, у нижніх горизонтах - фракції розміром 0,5-0,25 мм.

У чорноземах звичайних під насадженням акації білої в генетичних горизонтах також спостерігається домінування водостійкої фракції розміром $<0,25$ мм, при цьому 3 глибиною її вміст зростає. У горизонті Н спостерігається підвищення вмісту фракції розміром 1-0,5 мм, а в горизонтах $\mathrm{Hp}, \mathrm{Phk}$ та $\mathrm{Pk}$ - фракції розміром 0,5-0,25 мм.

Таблиця 2

Водостійкість агрегатів чорноземів звичайних під степовою та лісовою рослинністю

\begin{tabular}{|c|c|c|c|c|c|c|c|c|}
\hline \multirow{2}{*}{$\begin{array}{c}\text { Генетичний } \\
\text { горизонт }\end{array}$} & \multirow{2}{*}{ Глибина, см } & \multicolumn{7}{|c|}{ Уміст фракцій (мм), \% } \\
\hline & & $>5$ & $5-3$ & $3-2$ & $2-1$ & $1-0,5$ & $0,5-0,25$ & $<0,25$ \\
\hline \multicolumn{9}{|c|}{ Пробна площа № 201 - чорнозем звичайний під степовою рослинністю } \\
\hline $\mathrm{H}_{1}$ & $0-7$ & 2,9 & 4,4 & 6,2 & 14,4 & 18,1 & 15,9 & 38,1 \\
\hline $\mathrm{H}_{2}$ & $7-26$ & 0,8 & 1,6 & 3,6 & 13,2 & 23,2 & 20,5 & 37,1 \\
\hline Нр & $26-56$ & 0,0 & 0,5 & 3,4 & 11,9 & 23,6 & 22,9 & 37,6 \\
\hline Phk & $56-85$ & 0,4 & 0,1 & 2,4 & 10,9 & 24,9 & 26,1 & 35,1 \\
\hline $\mathrm{Pk}$ & $85-150$ & 0,6 & 0,0 & 1,0 & 6,4 & 15,9 & 25,5 & 50,6 \\
\hline \multicolumn{9}{|c|}{ Пробна площа № 224-а - чорнозем звичайний під насадженням акації білої } \\
\hline $\mathrm{H}$ & $0-14$ & 0,9 & 4,2 & 8,6 & 16,1 & 22,1 & 17,6 & 30,5 \\
\hline Нp & $14-34$ & 0,0 & 1,0 & 2,6 & 5,5 & 14,2 & 25,0 & 51,7 \\
\hline Phk & $34-56$ & 0,5 & 0,2 & 0,9 & 3,7 & 11,7 & 22,5 & 60,5 \\
\hline $\mathrm{Pk}$ & $56-120$ & 0,0 & 0,2 & 0,4 & 1,5 & 5,2 & 21,9 & 70,9 \\
\hline \multicolumn{9}{|c|}{ Пробна площа № 224-д - чорнозем звичайний під насадженням дуба звичайного } \\
\hline $\mathrm{H}_{1}$ & $0-10$ & 2,4 & 4,2 & 7,9 & 19,7 & 25,8 & 15,4 & 24,7 \\
\hline $\mathrm{H}_{2}$ & $10-35$ & 1,0 & 1,6 & 4,2 & 9,9 & 27,7 & 24,8 & 30,8 \\
\hline $\mathrm{Hp}$ & $35-70$ & 0,0 & 0,6 & 1,9 & 10,9 & 7,8 & 24,1 & 54,7 \\
\hline Phk & $70-100$ & 0,0 & 0,2 & 1,3 & 4,7 & 17,9 & 34,6 & 41,4 \\
\hline $\mathrm{Pk}$ & $100-150$ & 0,5 & 0,3 & 0,5 & 2,3 & 6,3 & 26,5 & 63,5 \\
\hline
\end{tabular}

Чорноземи звичайні під насадженням дуба характеризуються подібним до попередніх горизонтів переважанням фракції розміром $<0,25$ мм, при цьому 3 глибиною, як і в чорноземах під насадженням акації білої, спостерігається зростання іiї вмісту. У горизонтах $\mathrm{H}_{1}$ та $\mathrm{H}_{2}$ спостерігається збільшення вмісту водостійкої фракції розміром $1-0,5$ мм, а в горизонтах $\mathrm{Hp}, \mathrm{Phk}$ та $\mathrm{Pk}-$ фракції розміром $0,5-0,25 \mathrm{mм}$.

Таким чином, у чорноземах звичайних під степовою та лісовою рослинністю спостерігається переважання водостійкої фракції розміром $<0,25$ мм. Позитивний вплив насаджень акації білої та дуба звичайного на водостійкість агрегатів чорнозему звичайного проявляється у зменшенні вмісту фракції розміром $<0,25$ мм у верхніх горизонтах порівняно з чорноземом звичайним.

Розрахунок додаткових показників, який дозволяє виявити особливості структурно-агрегатного складу грунту (Teorii.., 2007, табл. 3), виявив, що максимальний уміст агрономічно цінних фракцій при сухому просіюванні в чорноземах звичайних під степовою рослинністю пов'язаний 3 горизонтами $\mathrm{Phk}$ та $\mathrm{Pk}$ (97,7 та 95,9 \% відповідно). Мінімальний уміст цих фракцій $(89,5 \%)$ виявлено в горизонті $\mathrm{H}_{1}, \quad 3$ глибиною спостерігається поступове зростання їх умісту (табл. 3). Максимальний уміст агрономічно цінних фракцій при мокрому просіюванні $(64,9 \%)$ виявлено в горизонті Phk. 3 глибиною спостерігається збільшення вмісту цієї фракції, а мінімальне значення $(49,4 \%)$ виявлено в горизонті $\mathrm{Pk}$. Уміст агрономічно цінних фракцій зростає з глибиною, досягаючи максимальної величини 194,1 в горизонті Pk. Величина критерію водоміцності також збільшується 3 глибиною, а його максимальний показник 543,5 виявлено в горизонті Phk.
У чорноземах звичайних під насадженням акації білої максимальний уміст агрономічно цінних фракцій при сухому просіюванні виявлено в горизонті Н (95,8 \%), 3 глибиною спостерігається зменшення цього показника. Максимальний уміст агрономічно цінних фракцій при мокрому просіюванні так само виявлено в горизонті $\mathrm{H}$ $(69,5 \%)$, а 3 глибиною відбувається зменшення їх умісту. Уміст агрономічно цінних фракцій збільшується 3 глибиною, а їх максимальний уміст виявлено в горизонті $\mathrm{Pk}(248,8)$. Збільшені значення критерію водоміцності виявлено в горизонтах Н та Phk (196,5 та 201,8 відповідно).

Збільшенні значення вмісту агрономічно цінних фракцій при сухому просіюванні виявлено в чорноземі звичайному під насадженням дуба звичайного в горизонті $\mathrm{H}_{2} \quad(96,0$ \%), при цьому 3 глибиною спостерігається зменшення ї умісту. Максимальний уміст агрономічно цінних фракцій при мокрому просіюванні характерний для горизонту $\mathrm{H}_{1} \quad(75,3 \%), \quad 3$ глибиною спостерігається зменшення їх умісту. Збільшений уміст агрономічно цінних фракцій виявлено в горизонтах Нp та $\mathrm{Pk}(207,3$ та 235,3 відповідно). Величини критерію водоміцності зростають з глибиною, досягаючи максимального значення в горизонті Phk $(566,3)$.

Таким чином, у чорноземах звичайних під степовою рослинністю найбільш сприятливі умови для формування агрономічно цінних фракцій при сухому просіюванні характерні для нижніх горизонтів, а для чорноземів під лісовими насадженнями - у верхніх горизонтах. В усіх досліджуваних грунтах найбільший уміст агрономічно цінних фракцій при мокрому просіюванні виявлено у верхніх горизонтах, однак у чорноземах під лісовими насадженнями він більший. Найбільший уміст агрономічно 
Таблиця 3

Порівняльна характеристика структурного складу чорноземів звичайних під степовою та лісовою рослинністю

\begin{tabular}{|c|c|c|c|c|}
\hline $\begin{array}{c}\text { Генетичний } \\
\text { горизонт }\end{array}$ & $\begin{array}{c}\text { Уміст агрономічно } \\
\text { цінних фракцій } \\
\text { при сухому просіюванні } \\
\text { (сума фракцій } \\
\text { 10,0-0,25 мм), \% }\end{array}$ & $\begin{array}{c}\text { Уміст агрономічно } \\
\text { цінних фракцій } \\
\text { при мокрому просіюванні } \\
\text { (сума фракцій більше } \\
0,25 \text { мм), \% }\end{array}$ & $\begin{array}{c}\text { Уміст агрономічно цінних } \\
\text { фракцій, } \\
\text { за С. І. Долговим } \\
\text { та П. У. Бахтіним } \\
\text { (співвідношення даних } \\
\text { сухого та мокрого } \\
\text { просіювання за сумою } \\
\text { агрегатів розміром } \\
\text { 0,25-10,0 мм) } \\
\end{array}$ & $\begin{array}{c}\text { Критерій АФІ } \\
\text { або критерій } \\
\text { водоміцності } \\
\text { (відношення суми } \\
\text { агрегатів } 1,0-0,25 \text { мм } \\
\text { при мокрому та сухому } \\
\text { просіюванні) }\end{array}$ \\
\hline \multicolumn{5}{|c|}{ Пробна площа № 201 - чорнозем звичайний під степовою рослинністю } \\
\hline $\begin{array}{c}\mathrm{H}_{1} \\
\mathrm{H}_{2} \\
\mathrm{Hp} \\
\mathrm{Phk} \\
\mathrm{Pk}\end{array}$ & $\begin{array}{l}89,5 \\
93,1 \\
94,2 \\
97,7 \\
95,9 \\
\end{array}$ & $\begin{array}{l}61,9 \\
62,9 \\
62,4 \\
64,9 \\
49,4 \\
\end{array}$ & $\begin{array}{r}144,6 \\
148,0 \\
151,0 \\
150,5 \\
194,1 \\
\end{array}$ & $\begin{array}{l}117,9 \\
272,6 \\
346,3 \\
543,5 \\
294,4\end{array}$ \\
\hline \multicolumn{5}{|c|}{ Пробна площа № 224-а - чорнозем звичайний під насадженням акації білої } \\
\hline $\begin{array}{c}\mathrm{H} \\
\mathrm{Hp} \\
\mathrm{Phk} \\
\mathrm{Pk}\end{array}$ & $\begin{array}{l}95,8 \\
91,1 \\
89,0 \\
72,4 \\
\end{array}$ & $\begin{array}{r}69,5 \\
48,3 \\
39,5 \\
29,1 \\
\end{array}$ & $\begin{array}{r}137,8 \\
188,6 \\
225,3 \\
248,8 \\
\end{array}$ & $\begin{array}{l}196,5 \\
152,0 \\
201,8 \\
157,0 \\
\end{array}$ \\
\hline \multicolumn{5}{|c|}{ Пробна площа № 224-д - чорнозем звичайний під насадженням дуба звичайного } \\
\hline $\begin{array}{c}\mathrm{H}_{1} \\
\mathrm{H}_{2} \\
\mathrm{Hp} \\
\mathrm{Phk} \\
\mathrm{Pk}\end{array}$ & $\begin{array}{l}92,2 \\
96,0 \\
93,9 \\
84,3 \\
85,9 \\
\end{array}$ & $\begin{array}{r}75,3 \\
69,2 \\
45,3 \\
58,6 \\
36,5 \\
\end{array}$ & $\begin{array}{l}122,4 \\
138,7 \\
207,3 \\
143,9 \\
235,3 \\
\end{array}$ & $\begin{array}{l}135,4 \\
210,0 \\
242,8 \\
566,3 \\
216,1\end{array}$ \\
\hline
\end{tabular}

цінних фракцій в усіх досліджуваних грунтах спостерігається в нижніх горизонтах, а їх найбільший уміст у верхніх горизонтах виявлено в чорноземах звичайних під степовою рослинністю. Найбільші значення критерію водоміцності характерні для нижніх горизонтів досліджуваних чорноземів. У цілому найбільші значення зазначеного критерію виявлені в чорноземі звичайному під насадженням дуба, а найменші - під насадженням акації.

\section{Висновки}

У результаті дослідження особливостей структурноагрегатного складу чорноземів звичайних під степовою та лісовою рослинністю встановлено, що в усіх досліджених грунтах найбільший уміст припадає на фракцію розміром 2-1 мм. У чорноземах звичайних у верхніх горизонтах під насадженнями акації білої та дуба звичайного спостерігається збільшення вмісту цієї агрономічно цінної фракції Також у чорноземі звичайному під лісовими насадженнями спостерігається збільшення величини коефіцієнта структурності порівняно 3 чорноземом звичайним під степовою рослинністю. У чорноземі звичайному найбільш сприятливий вплив зростання акації білої виявлено в горизонті $\mathrm{H}$, а зростання дуба звичайного - у горизонті $\mathrm{H}_{2}$, в яких виявлено найбільші значення коефіцієнта структурності. $\mathrm{y}$ досліджених чорноземах звичайних під степовою та лісовою рослинністю спостерігається переважання водостійкої фракції розміром $<0,25$ мм. Позитивний вплив насаджень акації білої та дуба звичайного на водостійкість агрегатів чорнозему звичайного проявляється у зменшенні вмісту фракції розміром $<0,25$ мм у верхніх горизонтах порівняно з чорноземом звичайним. У чорноземах звичайних під степовою рослинністю найбільш сприятливі умови для формування агрономічно цінних фракцій при сухому просіюванні характерні для нижніх горизонтів, а для чорноземів під лісовими насадженнями - у верхніх горизонтах. В усіх досліджуваних грунтах найбільший уміст агрономічно цінних фракцій при мокрому просіюванні виявлено у верхніх горизонтах, однак у чорноземах під лісовими насадженнями він більший. Найбільший уміст агрономічно цінних фракцій в усіх досліджуваних грунтах спостерігається у нижніх горизонтах, а їх найбільший уміст у верхніх горизонтах виявлено в чорноземах звичайних під степовою рослинністю. Найбільші значення критерію водоміцності характерні для нижніх горизонтів досліджуваних чорноземів. Максимальні значення зазначеного критерію виявлені в чорноземі звичайному під насадженням дуба, а найменші - під насадженням акації. Зростання лісових насаджень на чорноземах звичайних призводить до покращення їх структурно-агрегатного складу.

\section{References}

Belova, N. A. (1997). Ekologiya, mikromorfologiya, antropogenez lesnykh pochv stepnoj zony Ukrainy [Ecology, micromorfology, antropogenesis of forest soils in the Steppe zone of Ukraine]. Dnepropetrovsk University Press, Dnepropetrovsk (in Russian).

Belova, N. A., Travleyev, A. P. (1999). Estestvennye lesa i stepnye pochvy (ecologiia, mikromorfologiia, genesis), 1999 [Forest and steppe soils (ecology, micromorphology, genesis)]. Dnipropetrovsk (in Russian).

Cherednichenko, I. V. (2015). Strukturno-agregatnyy sklad chornozemu typovogo za riznykh system udobrennia [Structure-aggregate composition typical chernozem under different fertilized systems]. Bulletin of Kharkiv National Agrarian University. Seria «Soil science, agrochemistry, farming, forestry, ecology of soils», 1, 60-65 (in Ukrainian).

Degtyarev, V. V. (2011). Humus chornozemiv livoberezhnoho Lisostepu i Stepu Ukrainy [Humus of chernozems of left-bank forest-steppe and steppe of Ukraine]. Majdan, Kharkiv (in Ukrainian).

Desyatnik, K. O. (2015). Rol kaltsiyu v optymizatsii pokaznykiv rodyuchosti ta umov isnuvannia pedobiontiv $u$ chornozemi opidzolenomu [Role of calcium in optimization of fertility parameters and conditions of pedobiont existence in chernozems podzolized]. Gruntoznavstvo. 16(1-2), 52-59 (in Ukrainian).

Gholoubi, A., Emami, H., Caldwell, T. (2019). Deforestation effects on soil aggregate stability quantified by the high energy moisture characteristic method. Geoderma, 335, 113919.

Gorban, V. A. (2018). Diagnostychne znachennia fizychnykh vlastyvostei gruntiv lisovykh biogeotsenoziv stepovoi zony 
Ukrainy [Diagnostic role of soil physical properties of forest biogeocoenoses of the Ukrainian steppe zone]. Ecology and Noospherology, 29(2), 83-88.

Horn, R., Taubner, H., Wuttke, M., Baumgartl, T. (1994). Soil physical properties related to soil structure. Soil \& Tillage Research 30, 187-216.

Karpachevsky, L. O. (2005). Ekologicheskoe pochvovedenie [Ecological soil science], GEOS, Moscow (in Russian).

Krylach, S. I. (2016). Vplyv agrofizychnykh vlastyvostey posivnogo sharu chornozemu typovogo na prorostannia nasinnia silskogospodarskykh kultur [The impact of agrophysical properties of sowing layer of typical chernozem on the germination of seed crops]. Avtoref. dis. ... cand. silsk. nauk. Kharkiv (in Ukrainian).

Medvedev, V. V. (2008). Struktura pochvy (metody, genesis, klassifikatsiia, evolyutsia, geografiia, monitoring, okhrana) [Soil structure (methods, genesis, classification, evolution, geography, monitoring, protection)]. Kharkov, 13 tipografiia (in Russian).

Medvedev, V. V., Laktionova, T. N. (2011). Granulometricheskij sostav pochv Ukrainy (geneticheskij, ekologicheskij i agronomicheskij aspekty) [Texture of Ukrainian Soils (genetic, environmental and agronomical aspects)]. Apostrof, Kharkiv (in Russian).
Monreal, C. M., Schnitzer, M., Schulten, H.-R., Campbell, C. A., Anderson, D. W. (1995). Soil organic structures in macro and microaggregates of a cultivated brown chernozem. Soil Biol. Biochem. 27(6), 845-853.

Pituello, C., Ferro, N. D., Simonetti, G., Berti, A., Morari, F. (2016). Nano to macro pore structure changes induced by long-term residue management in three different soils. Agriculture, Ecosystems and Environment 217, 49-58.

Shein, E. V., Milanovskii, E. Yu. (2003). Rol i znachenie organicheskogo veshestva $\mathrm{v}$ obrazovanii $\mathrm{i}$ ustojchivosti pochvennykh agregatov [The role of organic matter in the formation and stability of soil aggregates]. Eurasian Soil Science 1, 53-61 (in Russian).

Šimanský, V. (2015). Dynamics of soil structure parameters in loamy soils of Slovakia. Soil Forming Factors and Processes from the Temperate Zone, 14, 1-8.

Teorii i metody fiziki pochv (2007) [Theories and techniques of soil physics]. Ed. E. V. Shein, L. O. Karpachevskij. Moscow (in Russian).

Vadyunina, A. F., Korchagina, Z. A. (1986). Metody issledovaniia fizicheskikh svojstv pochvy [Methods of study of the physical properties of soil]. Moscow (in Russian).

Voronin, A. D. (1986). Osnovy fiziki pochv [Basics of soil physics], Moscow University Press, Moscow (in Russian). 